\title{
SISTEM INFORMASI AKADEMIK UNTUK LAYANAN MAHASISWA UMS BERBASIS MOBILE
}

\author{
Hanif Amrullah, Bana Handaga \\ Program Studi Informatika Universitas Muhammadiyah Surakarta (UMS) \\ Surakarta, Indonesia \\ Hanifxamrullah@gmail.com, Bana.handaga@gmail.com
}

\begin{abstract}
Abstraksi - Pemanfaatan teknologi terkait penyampaian informasi dalam dunia akademik kini mulai bergeser dari teknologi web menjadi teknologi mobile yang lebih fleksibel, efektif, dan efisien.Meningkatnya akses informasi secara mobile tanpa diimbangi pengembangan yang baik dan serius akan menimbulkan masalah baru terkait keamanan sistem, kenyamanan dan kepuasan pengunaan teknologi mobile yang memiliki ukuran beragam. Oleh Karena itu, penelitian ini bertujuan untuk membangun sistem informasi akademik berbasis mobile native dengan sistem operasi android yang berfokus pada layanan akademik untuk mahasiswa di UMS. Sistem ini dibuat dengan Android Studio sebagai software IDE, java sebagai bahasa pemrogramannya dan API JSON utuk pertukaran datanya. Pengamatan secara langsung terhadap sistem informasi akademik UMS berbasis web dimaksudkan untuk pengumpulan data terkait fitur. Penelitian ini menghasilkan suatu sistem informasi akademik untuk layanan mahasiswa UMS berbasis mobile yang memiliki fitur cari jadwal, edit data diri, fitur terkait rencana studi, fitur lihat jadwal perkuliahan, fitur lihat nilai akademik, dan fitur atur password. Pengujian yang dilakukan terhadap 40 mahasiswa UMS dari beberapa program studi menunjukkan bahwa $88 \%$ responden menyetujui sistem ini mudah di gunakan, menarik, bermanfaat dan dibutuhkan oleh responden.
\end{abstract}

Katakunci-Sistem informasi; Akademik; Mobile; Android; API; JSON;

I.

\section{Pendahuluan (Heading 1)}

Kualitas komputasi smarthphone yang sebanding dengan komputer desktop meningkatkan penggunaan akses lalu lintas data secara mobile bagi mahasiswa di dalam institusi akademik [1]. Perubahan perilaku ini menuntut setiap institusi akademik melakukan optimalisasi sistem layanan akademik yang dimilikinya ke dalam teknologi mobile yang portabilitas, fleksibilitas, dan multifungsionalitas. Penerapan teknologi mobile berbasis android untuk e-learning di Politeknik Kabul Afghanistan telah meningkatkan $25 \%$ tingkat kelulusan dari kelompok yang terdaftar [2]. Penerapan teknologi mobile dengan pembuatan aplikasi android untuk broadcast pengumuman dengan teknik notifikasi via email antara departemen dalam sebuah institusi telah memberikan banyak kemudahan dalam mendapatkan dan menyampaian informasi [3]. Pemanfaatan teknologi mobile untuk mengontrol kipas angin dan lampu, jangkauan maksimal sejauh 9 meter melalui jaringan wifi UMS dengan webserver apache yang diinstall di Raspberry $\mathrm{Pi}$ [4].

Dalam penelitian sebelumnya [5] menyatakan bahwa layanan perguruan tinggi mulai mengadopsi aplikasi mobile sebagai prioriatas layanan utama karena ke populeran layanan mobile yang meningkat tiap tahunnya. Pada penelitian ini juga dilakukan perbandingan antara mobile app yang terpasang langsung dalam sistem operasi dengan mobile web yang diakses melalui browser. Data hasil dari penelitian ini adalah untuk layanan administrasi $(18,8 \%$ mobile apps), informasi umum (12,5\% mobile web dan $87,5 \%$ keduanya), informasi pribadi (62,5\% mobile apps), LMS (56,3\% mobile apps), produktivitas $(18,8 \%$ mobile apps dan $12,5 \%$ keduanya), layanan kemahasiswaan $(6,3 \%$ mobile apps, $37,5 \%$ mobile apps, dan $12,5 \%$ keduanya,), layanan 
perpustakaan(18,8\% mobile web, 25,0\% mobile apps, dan 31,3\% keduanya), layanan alumni (37,5\% mobile web), sedangakan untuk layanan lainnya $(12,5 \%$ baik untuk mobile web, mobile apps, maupun keduanya). Layanan yang disampaikan melalui aplikasi mobile lebih banyak dari pada melalui mobile web, yang menunjukkan bahwa aplikasi mobile adalah alat utama yang cocok digunakan untuk perguruan tinggi di Taiwan selain memang untuk kegiatan yang bersifat rutinitas layanan mobile apps lebih umum digunakan dibandingkan mobile web.

Merujuk pada uraian penelitian diatas dapat disimpulkan bahwa pembuatan Sistem informasi akademik berbasis mobile dengan sistem operasi android merupakan pembaharuan teknologi informasi yang tepat untuk memenuhi kebutuhan layanan informasi dalam institusi. Maka dengan kesimpulan tersebut tujuan dari penelitian ini adalah membuat sistem informasi akademik untuk layanan mahasiswa UMS berbasis mobile. Penulis berharap dengan dibuatnya sistem ini mahasiswa UMS dapat merasakan kemudahan,kenyamanan dalam penggunaan sistem informasi akademik secara mobile.

\section{DASAR TeORI DAN Tinjauan PUStaKa}

Sistem informasi manajemen dalam dunia akademik dengan teknologi informasinya telah meningkat pesat dikarenakan efisiensi dan efektivitasnya [6]. Pengadopsian sistem keteknologi mobile native sebagai tahap awal umumnya lebih menargetkan kepada sistem operasi dengan pengguna terbanyak. Sistem operasi android kini berhasil mengusai pangsa pasar secara global yaitu sekitar 70\% [7].

Menurut [8] menyatakan bahwa android studio merupakan tool resmi yang memiliki kredibilitas dan ditujukkan bagi pengembang aplikasi android native. Pemrograman multiplatform umumnya membutuhkan Aplication Programming Interface (API) dengan format data JSON atau XML yang memungkinkan programmer untuk menggunakan fungsi standar dalam berinteraksi dengan sistem operasi lain.

\section{Metode Penelitian}

Penelitian ini menggunakan software Android studio untuk membuat aplikasi berbasis android dengan bahasa pemrograman java sebagai objek utama, objek pendukung berupa webservice yang dibuat dari bahasa pemrograman $P H P$ dengan database Mysql dan digunakan sebagai sampel pemodelan API yang berformat JSON dari website Sistem Informasi Akademik UMS

\section{A. Analisa kebutuhan akan sistem}

Pada tabel 1 dibawah ini merupakan rincian dari kebutuhan hardware maupun software yang dibutuhkan dalam pembuatan sistem ini.

Tabel 1. Kebutuhan Hardware dan Software

\begin{tabular}{|ll|lll|}
\hline \multicolumn{1}{|c|}{ Kebutuhan hardware } & \multicolumn{3}{|c|}{ Kebutuhan software } \\
\hline a. & Laptop TOSHIBA & a. & Android Studio 2.3.3 \\
& Satellite C55t-C & b. & Atom & \\
intel@ Core@ i3- & c. & Postman & \\
5020U CPU @ & d. & Browser chrome & \\
2.20GHz, Ram 12 & & v.61.0.3163.100 & \\
GB, Hardisk & e. & Hosting & \\
1000GB & f. & CorelDraw X7 & \\
Smartphone merk & g. & Java & 8(JDK \\
Xiaomi Redmi & & $\left.1.8 .0 \_101\right)$ & \\
Prime 2 dengan OS & h. Android SDK & tools \\
Android version & & 25.1 .1 & \\
5.1.1 LMY47V API & & & \\
level 22 & & & \\
& & & \\
\end{tabular}

\section{B. Pengumpulan data}

situs https://akademik.ums.ac.id dan https://star.ums.ac.id diadopsi ke teknologi mobile sebagai pengumpulan data. Fitur yang harus ada di activity awal aplikasi android diantaranaya adalah fitur menampilkan halaman home beserta pengumuman,fitur untuk login beserta autentikasinya, fitur untuk cari jadwal berdasarkan kategori jurusan, dosen, ruang, dan matakuliah. Sedangkan di activity selanjutnya setelah berhasil loginj ada fitur untuk direct link halaman kalender akademik dan pendaftaran wisuda, fitur lihat dan edit data diri, fitur lihat dan isi Kartu Rencana Studi (KRS), fitur lihat jadwal kuliah, fitur 
lihat perkembangan studi, fitur halaman setting password dan fitur Logout beserta destroy autentikasi untuk keluar dari sitem.

\section{Arsitektur Sistem}

Database Mysql akan memberikan result data berdasarkan request query dari program PHP, jika response sesuai maka output berupa data berformat JavaScript Object Notation $(J S O N)$. Data JSON yang ringan dan dapat direpresentasikan oleh semua bahasa pemrograman dalam berbagai platform dijadikan sebagai API atau Application Programming Interface dalam sistem ini. File PHP dan database Mysql di upload ke dalam web hosting supaya dapat di jadikan sebagai Rest Server sehingga dapat diakses secara online oleh Rest Client seperti android. Retrofit merupakan library Rest Client untuk android yang dimanfaatkan dalam mengirimkan request dan menerima response dengan method POST, GET, PUT, dan
DELETE ke Rest Server penyedia API. Data response kemudian akan dimodelkan oleh java yang terintegrasi dengan file $\mathrm{xml}$ atau layoutingnya supaya tampil di layar device mobile.

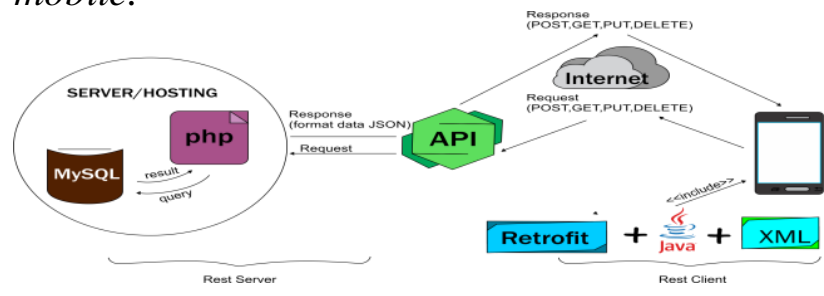

Gambar 1. Arsitektur SIA UMS berbasis mobile

\section{Perancangan Sistem}

Perancangan sistem dibagi menjadi tiga tahap yaitu use case diagram, activity diagram, dan entity relationship diagram.

1. Use Case Diagram

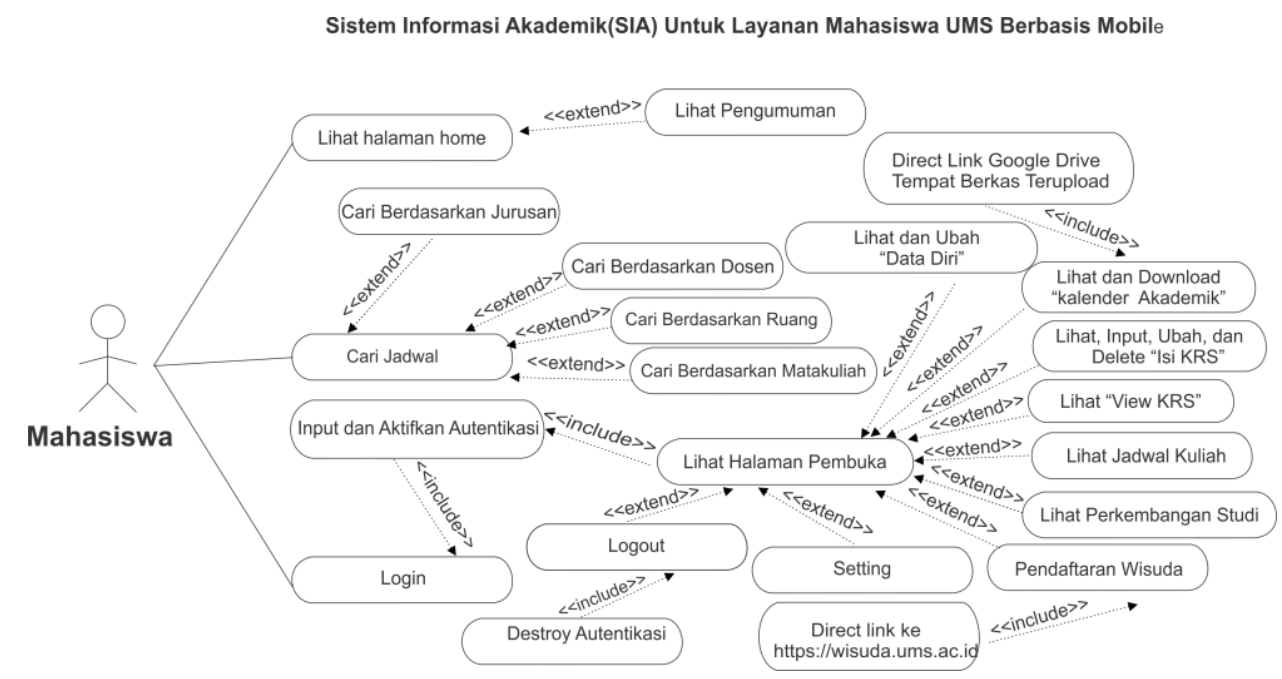

Gambar 2. Use case SIA UMS berbasis mobile

Mahasiswa di dalam use case diagram ini( lihat gambar 2) secara otomatis setelah sistem dijalankan dapat melakukan akses ke halaman home yang didahului dengan pengumuman, halaman cari jadwal yang dapat digunakan pencarian jadwal(berdasarkan jurusan/dosen/ruang/matakuliah), dan halaman login untuk masuk ke sistem dengan autentikasi. Selain itu terdapat juga beberapa use case yang dapat diakses setelah proses autentikasi berhasil diantaranya lihat dan ubah data diri, direct link kalender akademik dan halaman pendaftaran wisuda, isi KRS, lihat View KRS, lihat jadwal kuliah, lihat perkembangan studi, setting password dan logout untuk keluar dan menghilangkan autentikasi. 
2. Activity Diagram 


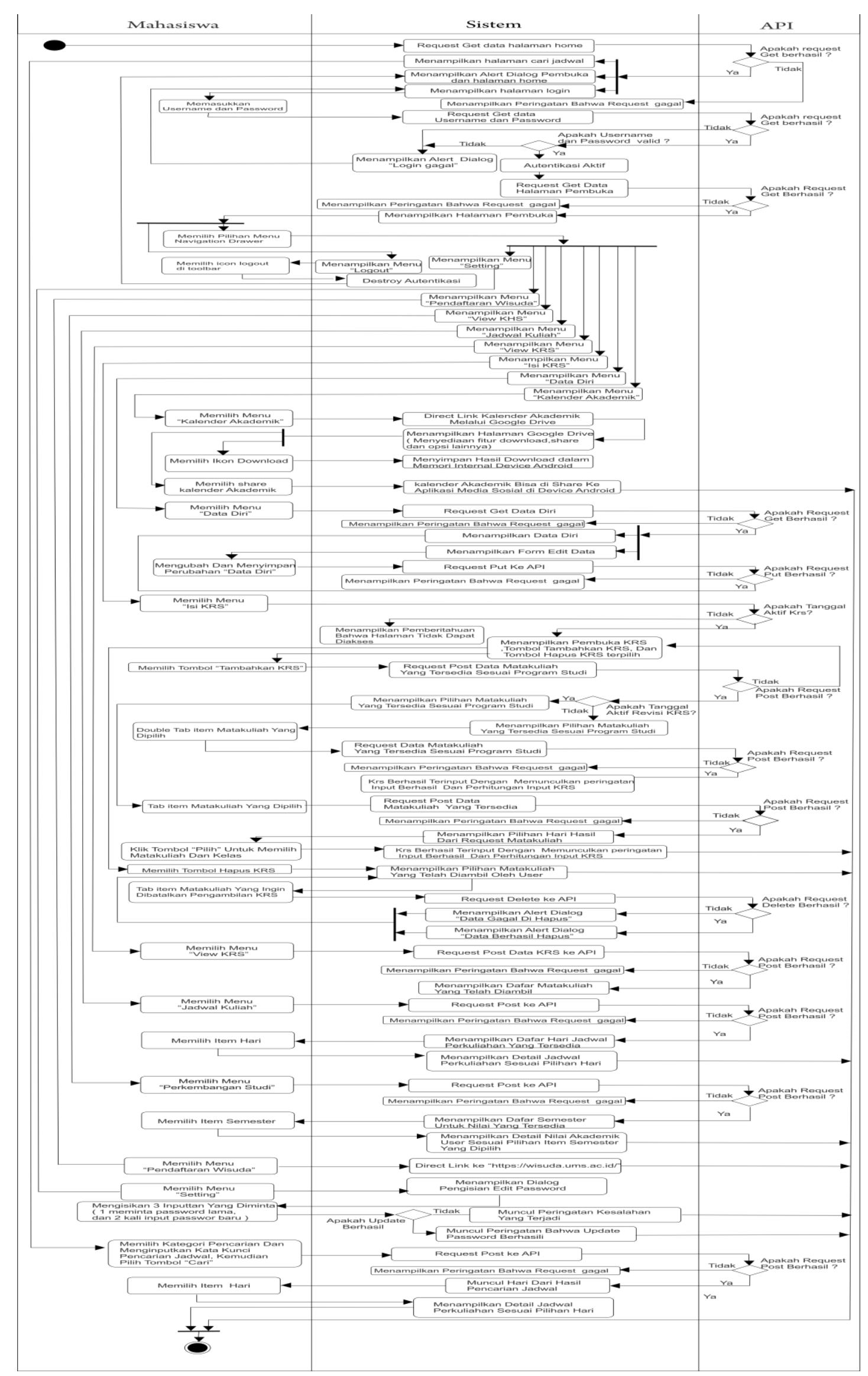

Gambar 3. Activity diagram SIA berbasis mobile 
Activity diagram ( lihat gambar 3) menggambarkan urutan activitas dalam sistem dan sekaligus memberikan pehaman proses secara keseluruhan.

\section{Entity Relationship Diagram}

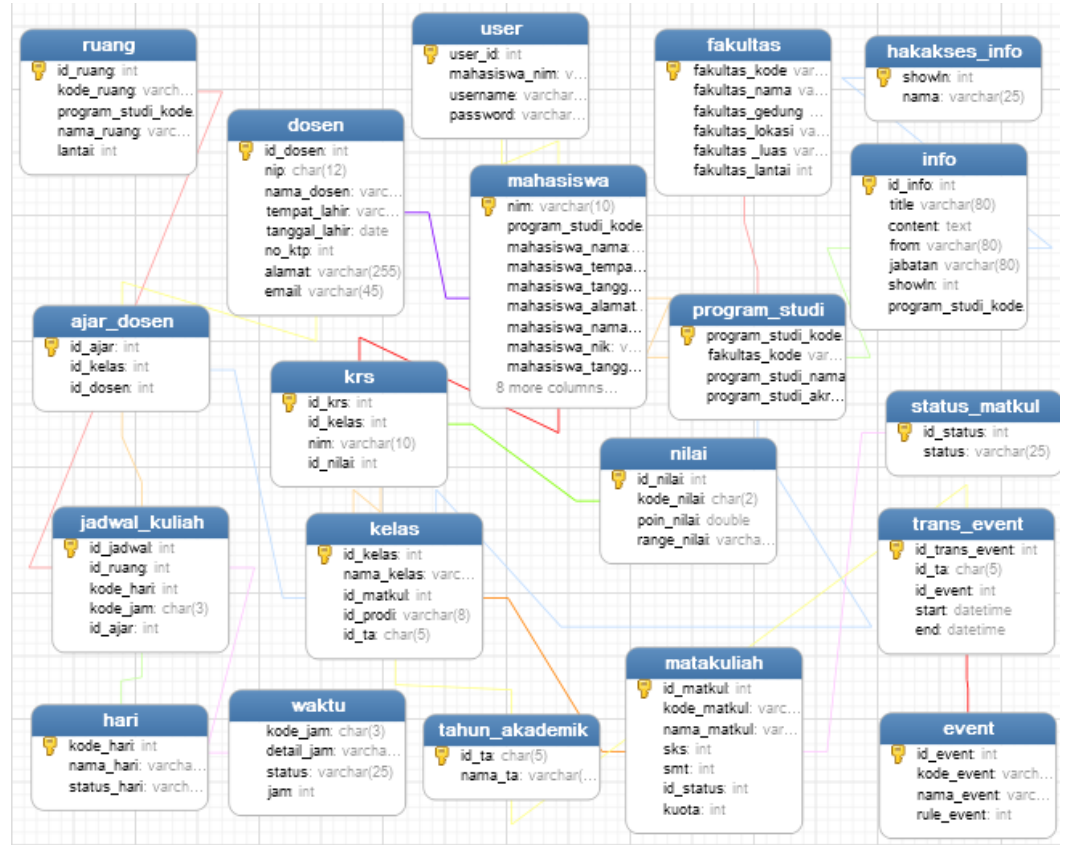

Gambar 4. ERD SIA UMS berbasis mobile

\section{E. Pengujian}

Pengujian sistem menggunakan metode blackbox dengan poin - poin pengujian seperti kebenaran apakah hasil dari proses input dan output sistem sesuai dengan harapan, setelah itu pengujian lainnnya adalah uji terhadap berbagai density (kepadatan pixel), resolusi layar dan size berbagai varian mobile.

\section{HASIL DAN PEMBAHASAN}

Hasil dari sistem ini adalah sebuah aplikasi berekstensi .apk dengan ukuran $21 \mathrm{MB}$ yang digunakan dalam memudahkan mahasiswa mengakses sitem informasi akademik UMS secara mobile.

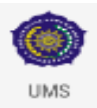

\section{Gambar 5. Ikon launcher}

Pada gambar 5 merupakan ikon launcher dari sistem informasi akademik UMS berbasis mobile.

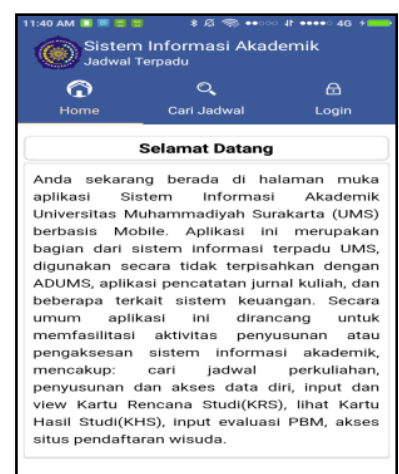

(a) halaman awal

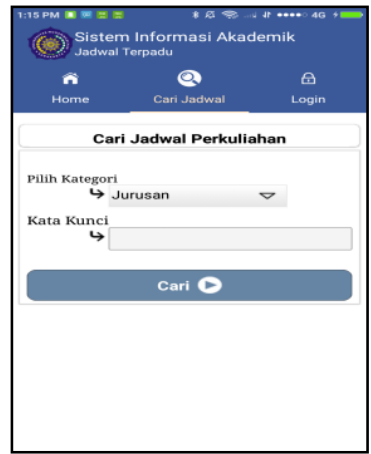

(b) halaman cari jadwal

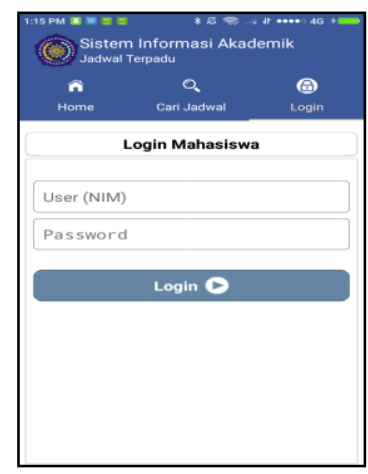

(c)halaman login 
Gambar 6. Activity awal saat aplikasi di jalankan petama kali

Tampilan awal saat aplikasi pertama dijalankan adalah seperti gambar 6(a) yang halaman awal aplikasi 6(b) merupakan t fitur cari jadwal yang digunakan untuk mencari jadwal berdasarkan kategori dan kata kunci

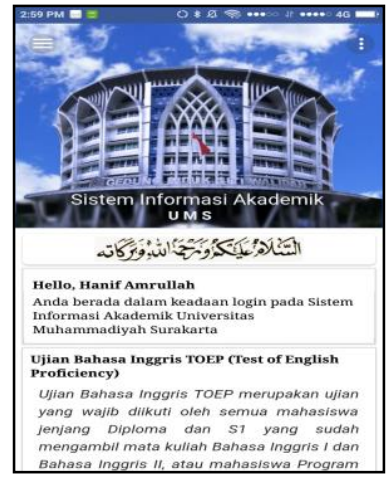

(a) halaman home

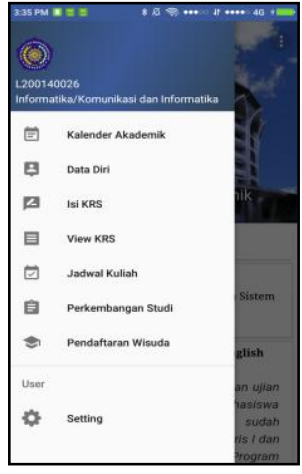

(b) navigasi menu yang di inputkan, dan pada gambar 6(c) merupakan fitur untuk melakukan login. Semua halaman pada gambar 6 bisa di akses dengan melakukan tab pada ikon masing masing atau swap layar kekiri dan kekanan.

Gambar 7. Activity kedua setelah berhasil login

Tampilan seteah user berhasil login adalah seperti gambar 7(a). Pada gambar 7(a) terdapat juga gambar header, ikon di pojok atas kiri untuk membuka naviagasi, dan ikon di pojok kanan atas untuk logout dari sistem. Menu menu yang menyangkut fitur - fitur terdapat dalam navigasi bar, lihat gambar 7(b). Pada tampilan gambar 7(c) merupakan fitur untuk ubah password dengan ketentuan untuk memasukkan password lama terlebih dahulu sebagai keamanan kemudian input dan reinput password baru yang akan di simpan.

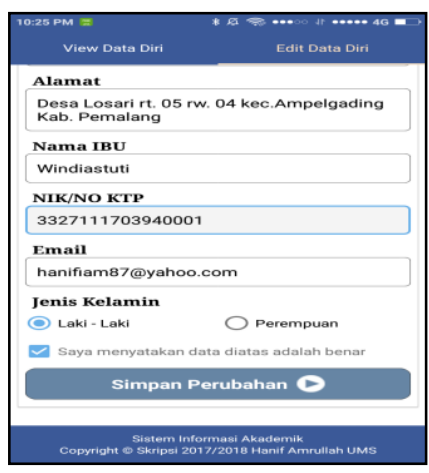

(a) edit data diri

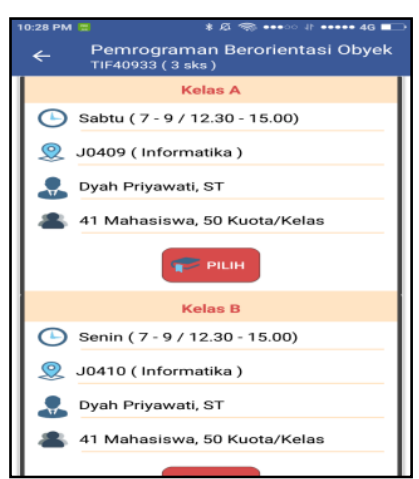

(b) pilih kelas

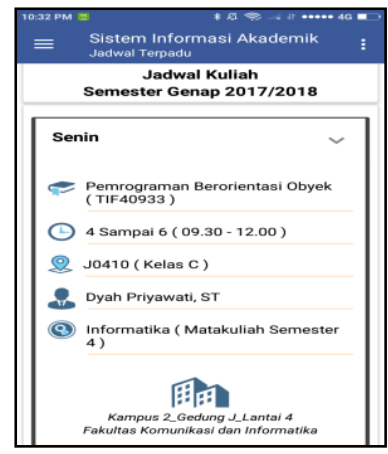

(c)lihat jadwal kuliah

Gambar 8. Activity beberapa fitur

Pada gambar 8(a) ditunjukkan fitur untuk update data diri,sedangkan pada gambar 8(b) merupakan tampilan pilih kelas dari halaman isi rencana studi saat revisi KRS. Pada halaman isi KRS sendiri terdapat tanggal yang membedakan antara KRS aktif, revisi KRS, dan KRS tidak aktif. Perbedaan masing masing state pada KRS adalah jika merupakan revsisi KRS maka user dapat memilih matakuliah dan kelas yang masih tersedia 
sedangkan jika pada state KRS aktif hanya memilih matakuliah yang dipilih. Pada gambar 8(c) merupakan tampilan saat mengakses halaman jadwal kuliah yang dikelompokkan berdasarkan hari, sedangkan fitur untuk perkembangan studi merupakan tampilan halaman perkembangan studi yang dikelompokkan berdasarkan semester dan matakuliah pilihan.

Pengujian blackbox sistem ini dilkukan untuk memastikan bahwa sistem berjalan dengan apa yang diharapkan untuk semua test case yang dilakukan. Tabel 2 dibawah ini merupakan penjabaran hasil pengujian yang telah dilakukan.

Tabel 2. Uji blackbox SIA UMS berbasis mobile

\begin{tabular}{|c|c|c|c|}
\hline Test Case & Input & Output & Kesimpulan \\
\hline \multirow{2}{*}{$\begin{array}{l}\text { Pada proses } \\
\text { cari jadwal }\end{array}$} & $\begin{array}{l}\text { Memilih Kategori } \\
\text { jurusan, ruang, dosen } \\
\text { maupun matakuliah ) dan } \\
\text { isi kata kunci }\end{array}$ & $\begin{array}{l}\text { Hasil sesuai dengan kategori } \\
\text { dan kata kunci yang di } \\
\text { masukkan }\end{array}$ & \multirow[t]{2}{*}{ Diterima } \\
\hline & Tidak mengisi kata kunci & $\begin{array}{l}\text { Muncul alert peringatan } \\
\text { error }\end{array}$ & \\
\hline \multirow{2}{*}{$\begin{array}{l}\text { Pada proses } \\
\text { login }\end{array}$} & $\begin{array}{l}\text { Username dan password } \\
\text { valid }\end{array}$ & $\begin{array}{l}\text { Masuk ke halaman home } \\
\text { dan dapat mengakses fitur - } \\
\text { fitur yang tersedia }\end{array}$ & \multirow{2}{*}{ Diterima } \\
\hline & $\begin{array}{l}\text { Username atau password } \\
\text { tidak valid bahkan } \\
\text { dikosongkan }\end{array}$ & $\begin{array}{l}\text { Muncul alert peringatan } \\
\text { error }\end{array}$ & \\
\hline \multirow[b]{2}{*}{$\begin{array}{l}\text { Pada direct } \\
\text { link }\end{array}$} & $\begin{array}{l}\text { Pilih menu kalender pada } \\
\text { navigasi bar }\end{array}$ & $\begin{array}{l}\text { Menuju link kalender } \\
\text { akademik terupload }\end{array}$ & \multirow[t]{2}{*}{ Diterima } \\
\hline & $\begin{array}{l}\text { Pilih menu Pendaftaran } \\
\text { Wisuda pada navigasi } \\
\text { bar }\end{array}$ & $\begin{array}{l}\text { Menuju link website } \\
\text { https://wisuda.ums.ac.id }\end{array}$ & \\
\hline \multirow{2}{*}{$\begin{array}{lr}\text { Pada } & \text { proses } \\
\text { Update } & \text { data } \\
\text { diri } & \end{array}$} & $\begin{array}{l}\text { Inputan untuk nama, nim, } \\
\text { program studi tidak } \\
\text { kosong }\end{array}$ & Data diri berhasil di update & \multirow{2}{*}{ Diterima } \\
\hline & $\begin{array}{l}\text { Jika Inputan untuk nama, } \\
\text { nim, program studi } \\
\text { dikosongkan }\end{array}$ & $\begin{array}{l}\text { Muncul alert peringatan } \\
\text { error dan data diri gagal di } \\
\text { update }\end{array}$ & \\
\hline $\begin{array}{l}\text { Pada Proses } \\
\text { pengaksesan } \\
\text { halaman isi } \\
\text { KRS }\end{array}$ & $\begin{array}{l}\text { Pilih menu isi KRS pada } \\
\text { navigasi bar }\end{array}$ & $\begin{array}{l}\text { Masuk akses (KRS aktif } \\
\text { atau revisi KRS) saat date } \\
\text { now diantara tanggal mulai } \\
\text { dan berakhirnya KRS aktis } \\
\text { atau Revisi KRS }\end{array}$ & Diterima \\
\hline
\end{tabular}




\begin{tabular}{|c|c|c|c|}
\hline & & $\begin{array}{l}\text { Masuk akses peringatan } \\
\text { halaman tidak dapat di akses } \\
\text { saat tidak masuk di range } \\
\text { KRS aktif maupun revisi } \\
\text { KRS }\end{array}$ & \\
\hline $\begin{array}{l}\text { Pada proses } \\
\text { input KRS }\end{array}$ & $\begin{array}{l}\text { Double tab matakuliah } \\
\text { yang di pilih( } \\
\text { KRS ) antuk aktif } \\
\text { matakuliah atau Tab } \\
\text { pilih kelas ( untuk revisi } \\
\text { KRS ) }\end{array}$ & $\begin{array}{l}\text { Data pilihan KRS berhasil } \\
\text { terinput. }\end{array}$ & Diterima \\
\hline $\begin{array}{l}\text { Pada proses } \\
\text { batalkan KRS }\end{array}$ & $\begin{array}{l}\text { Double tab matakuliah } \\
\text { yang akan dibatalkan }\end{array}$ & $\begin{array}{l}\text { Matakuliah berhasil } \\
\text { terhapus }\end{array}$ & Diterima \\
\hline \multirow{5}{*}{$\begin{array}{l}\text { Pada proses } \\
\text { view data }\end{array}$} & $\begin{array}{l}\text { Pilih tombol tambahkan } \\
\text { KRS }\end{array}$ & $\begin{array}{l}\text { Menampilkan daftar pilihan } \\
\text { matakuliah sesuai program } \\
\text { studi user dan yang belum } \\
\text { pernah di input user dalam } \\
\text { satu tahun akademik }\end{array}$ & \multirow{5}{*}{ Diterima } \\
\hline & $\begin{array}{l}\text { Pilih tombol batalkan } \\
\text { KRS }\end{array}$ & $\begin{array}{l}\text { Menampilkan matakuliah } \\
\text { yang telah diinputkan oleh } \\
\text { user }\end{array}$ & \\
\hline & $\begin{array}{l}\text { Pilih menu View KRS } \\
\text { pada navigasi bar }\end{array}$ & $\begin{array}{l}\text { Menampilkan hasil input } \\
\text { KRS yang diambil }\end{array}$ & \\
\hline & $\begin{array}{l}\text { Pilih menu Jadwal Kuliah } \\
\text { pada navigasi bar }\end{array}$ & $\begin{array}{l}\text { Menampilkan Jadwal } \\
\text { perkuliahan Matakuliah } \\
\text { yang di ambil user }\end{array}$ & \\
\hline & $\begin{array}{lr}\text { Pilih } & \text { menu } \\
\text { Perkembangan } & \text { Studi } \\
\text { pada navigasi bar } & \end{array}$ & $\begin{array}{l}\text { Menampilkan } \\
\text { akademik } \text { user }\end{array}$ & \\
\hline $\begin{array}{l}\text { Setting } \\
\text { Password }\end{array}$ & $\begin{array}{l}\text { Input password lama } \\
\text { valid dan input password } \\
\text { baru match }\end{array}$ & Password berhasil di update & Diterima \\
\hline $\begin{array}{l}\text { Pada proses } \\
\text { logout }\end{array}$ & $\begin{array}{l}\text { Pilih menu LogOut di } \\
\text { pojok kanan atas bagian } \\
\text { toolbar }\end{array}$ & $\begin{array}{l}\text { Aplikasi berhasil keluar dan } \\
\text { menuju halaman awal, } \\
\text { autentikasi juga sudah tidak } \\
\text { berfungsi lagi. }\end{array}$ & Diterima \\
\hline
\end{tabular}

Pengujian lainnya yang dilakukan oleh penulis adalah uji terhadap berbagai density (kepadatan pixel), resolusi layar dan size berbagai varian mobile dengan menggunakan 
AVD (Android Virtual Devices) yang tersedia merupakan daftar hasil pengujiannya. di Android Studio. Tabel 3 di bawah ini

Tabel 3. Daftar uji coba aplikasi pada berbagai varian mobile

\begin{tabular}{|c|c|c|c|}
\hline Nama AVD & Nama OS & Size/resolusi/Density & Hasil \\
\hline QVGA & Lollipop (API 22) & $2,7 " / 240 \times 320 / 1 \mathrm{dpi}$ & OK \\
\hline QVGA (ADP2) & Marshmallow (API 23) & $3,2 " / 320 \times 480 / \mathrm{mdpi}$ & OK \\
\hline Nexus S & Nougat (API 24) & $4,0 " / 480 \times 800 / \mathrm{hdpi}$ & OK \\
\hline Nexus 4 & Nougat (API 25 ) & $4,7 \% / 768 \times 1280 / \mathrm{xhdpi}$ & OK \\
\hline Pixel & Oreo (API 26) & $5,0 " / 1080 \times 1920 / \mathrm{xxhdpi}$ & OK \\
\hline WSVGA (Tablet) & Lollipop (API 22) & $7,0 " / 600 \times 1024 / \mathrm{mdpi}$ & OK \\
\hline Nexus 10 (Tablet) & Oreo (API 26) & $10,05 " / 2560 \times 1600 / \mathrm{xhdpi}$ & OK \\
\hline
\end{tabular}

Proses pengujian selanjutnya adalah pengujian terhadap calon user yaitu mahasiswa UMS dari berbagai program studi. Pengujian dilakukan dengan cara mencoba poin - poin test case aplikasi secara langsung oleh responden beserta pengisian kuisioner. Jumlah keseluruhan responden sebanyak 40 responden mahasiswa UMS, yaitu dari program studi pendidikan bahasa Indonesia (1 responden), pendidikan bahasa inggris (1 responden), manajemen (1 responden), akuntansi (2 responden), ilmu ekonomi studi pembangunan (4 responden), geografi (1 responden), pendidikan teknik informatika (1 responden), teknik industri (1 responden), hukum (2 responden), ilmu gizi (3 responden), kesehatan masyarakat (3 responden), farmasi (7 responden), pendidikan agama islam (7 responden), hukum ekonomi syariah (2 responden), dan informatika ( 4 responden ). Tabel 4 di bawah ini merupakan tabel daftar kode pertanyaan dan pertanyaannya dari kuisioner yang dibagikan kepada responden.

Tabel 4. Daftar kode pertanyaan dan pertanyaan kuisioner

\begin{tabular}{|c|c|}
\hline Kode Pertanyaan & Pertanyaannya \\
\hline P1 & Aplikasi mudah digunakan \\
\hline $\mathrm{P} 2$ & Tampilan dan tata letak aplikasi menarik \\
\hline $\mathrm{P} 3$ & $\begin{array}{l}\text { Proses atau performa penampilan dan pengolahan data berjalan } \\
\text { dengan baik }\end{array}$ \\
\hline P4 & Content yang ditampilkan jelas, lengkap, dan sesuai kebutuhan \\
\hline P5 & Proses keamanan akun pengguna sudah baik dan mudah diatur \\
\hline P6 & $\begin{array}{l}\text { Aplikasi dapat meningkatkan kenyamanan dan kecepatan akses } \\
\text { mahasiswa dalam menggunakan sistem informasi akademik UMS } \\
\text { secara mobile }\end{array}$ \\
\hline P7 & Aplikasi ini dibutuhkan dan bermanfaat bagi mahasiswa ums \\
\hline
\end{tabular}

Keterangan poin atau nilai dari pengisian kuisioner adalah sebagai berikut, SS jika sangat setuju (Nilai 5), S jika setuju (Nilai 4), $\mathrm{N}$ jika netral (Nilai 3), TS jika tidak setuju 
(Nilai 2), dan STS jika sangat tidak setuju (Nilai 1).
Nilai Nmax di dapat dari persamaan 2 ...............(2)

\section{Eresponden x 5}

Hasil kuisioner calon user adalah dengan Persamaan 1.

Presentase $=($ Enilai $\mathrm{x} 100 \%) \div$ Nmax.......(1)

Jumlah responden pada penelitian ini sejumlah 40 responden, sehingga Nilai Tertinggi $(\mathrm{Nmax})=\mathbf{5} \times \mathbf{4 0}=\mathbf{2 0 0}$

Tabel 5. Hasil perhitungan kuisoner

\begin{tabular}{|c|c|c|c|c|c|c|c|c|}
\hline \multirow{2}{*}{ No } & \multirow{2}{*}{$\begin{array}{c}\text { Kode } \\
\text { Soal }\end{array}$} & $\begin{array}{c}\text { SS } \\
(5)\end{array}$ & $\begin{array}{c}\text { S } \\
(4)\end{array}$ & $\begin{array}{c}\text { N } \\
(3)\end{array}$ & $\begin{array}{c}\text { TS } \\
(2)\end{array}$ & $\begin{array}{c}\text { STS } \\
(1)\end{array}$ & $\begin{array}{c}\text { Juml } \\
\text { nilai }\end{array}$ & $\begin{array}{c}\text { PI } \\
(\%)\end{array}$ \\
\hline 1 & P1 & 25 & 15 & 0 & 0 & 0 & 185 & $92,5 \%$ \\
\hline 2 & P2 & 14 & 23 & 3 & 0 & 0 & 171 & $85,5 \%$ \\
\hline 3 & P3 & 10 & 25 & 5 & 0 & 0 & 165 & $82,5 \%$ \\
\hline 4 & P4 & 17 & 20 & 3 & 0 & 0 & 174 & $87 \%$ \\
\hline 5 & P5 & 15 & 15 & 10 & 0 & 0 & 165 & $82,5 \%$ \\
\hline 6 & P6 & 27 & 10 & 3 & 0 & 0 & 184 & $92 \%$ \\
\hline 7 & P7 & 29 & 10 & 1 & 0 & 0 & 188 & $94 \%$ \\
\hline
\end{tabular}

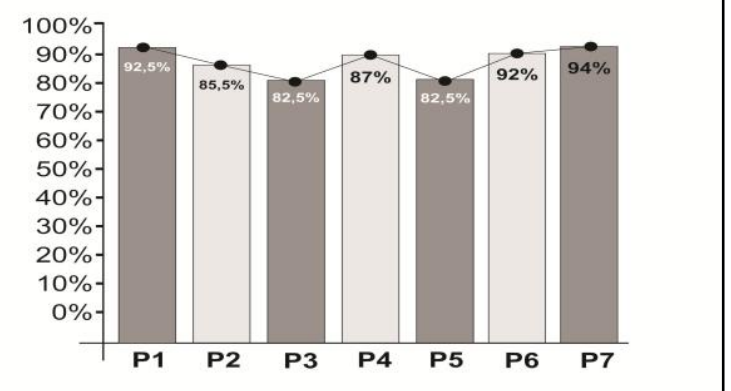

Gambar 9. Grafik penilaian pengisian kuisioner

Analisa berdasarkan tabel 5 dan gambar 9 menunjukkan hasil bahwa $88 \%$ aplikasi sistem informasi akademik UMS berbasis mobil dibutuhkan oleh mahasiswa UMS karena mampu memberikan kemudahan baik secara content, akses maupun proses yang lebih stabil 


\section{KESIMPULAN}

Sistem informasi akademik UMS berbasis mobile yang dibangun untuk layanan mahasiswa telah diselesaikan sesuai dengan tujuan awal pembuatan sistem. Hal ini dapat dianalisa dari hasil pengujian blackbox yang menunjukkan semua test case baik secara tampilan maupun proses dapat berjalan dengan baik di semua varian size, resolusi maupun density perangkat mobile.

Selain itu tercapainya tujuan sitem ini juga dapat dilihat dari penilaian calon user yang menunjukkan 92\% menyatakan aplikasi mudah digunakan, $85,5 \%$ menyatakan tampilan dan tata letak apliaksi menarik, 82,5\% menyatakan aplikasi memiliki proses dan performa yang baik, $87 \%$ menyatakan content jelas, lengkap, dan sesuai kebutuhan, 82,5\% menyatakan proses keamanan akun pengguna sudah baik dan mudah diatur, $92 \%$ menyatakan aplikasi dapat meningkatkan kenyamanan dan kecepatan akses, dan 94\% menyatakan aplikasi dibutuhkan dan bermanfaat bagi mahasiswa UMS.

Saran untuk pengembangan sistem ini adalah masih perlunya penambahan fitur terkait ujian mahasiswa, penilaian dosen, dan perhitungan tagihan pembayaran supaya dapat menyesuaikan dengan sitem informasi akademik UMS yang berbasis website.

\section{Daftar Pustaka}

[1] Lau, K. P., Chiu, D. K. W., Ho, K. K. W., Lo. P., \& See-To. E. W. K.(2017).Differences Between Postgraduate and Undergraduate Students. The Journal of Academic Librarianship, 43(3), 201-208. doi: https://doi.org/10.1016/j.acalib.2017.03.

[2] Kabiri, M. N., \& Wannous, M. (Eds.). (2017). The use cloud computing and mobile technologies to facilitate access to e-learning solution in higher education context work in progress. Proceedings of the IEEE International Conference on Applied System Innovation, Sapporo,
Japan, May 13-17. Applied system innovation (ICASI). doi: 10.1109/ICASI.2017.7988301.

[3] Golhar, R.V., Vyawahare, P. A., Borghare, P. H., \& Manusmare, A. (2016). Design and implementation of android base mobile app for an institute. International Conference on Electrical, Electronics, and Optimization Techniques (ICEEOT), Chennai, India, March 3-5. ICEEOT: IEEE.

doi:10.1109/ICEEOT.2016.7755391.

[4] Hermawan, D., \& Muhammad, H. (2017). Pengendali lampu dan kipas angin dari jarak jauh dengan wifi dan raspberry pi. Perpustakaan Universitas Muhammadiyah Surakarta.

[5] Cheng, H., Kung, T., Li, C., \& Sun, Y. (2016). The current state of mobile apps development of higher educational in Taiwan. ICACT Transactions on Advanced Communications Technology (TACT), 5(2),780-786. doi:10.23919/ICACT.2017.7890227

[6] Shah, M.(2014). Impact of management information systems (MIS) on school administration: What the literature says. Procedia-Social and Behavioral Sciences, 116, 2799-2840. doi: https://doi.org/10.1016/j.sbspro.2014.01.65 9

[7] Novac, O.C., Gordan, C., Novac, M., Berczes, T., \& Bujdosó, G. (2017). Comparative study of google android, apple iOS and microsoft windows phone mobile operating systems. 14th International Conference on Engineering of Modern Electric Systems (EMES),Oradea, Romania, June 1-2. Engineering of Modern Electric Systems (EMES):IEEE. doi: 10.1109/EMES.2017.7980403.

[8] Yener, M., \& Dundar, O.(2016).Expert Android Studio.Retrived September.New York(NYK):Wrox. 